\title{
Duodenum has the greatest potential to absorb soluble non-ammonia nitrogen in the nonmesenteric gastrointestinal tissues of dairy cows"
}

\author{
Ying-ming XIE ${ }^{\S}$, Qing-biao XU ${ }^{\S}$, Yue-ming WU ${ }^{\dagger \ddagger}$, Xin-bei HUANG, Jian-xin LIU \\ (Institute of Dairy Science, MoE Key Laboratory of Molecular Animal Nutrition, \\ College of Animal Sciences, Zhejiang University, Hangzhou 310058, China) \\ †E-mail: ymwu@zju.edu.cn
}

Received Nov. 7, 2014; Revision accepted Mar. 22, 2015; Crosschecked May 13, 2015

\begin{abstract}
In cattle, dietary protein is gradually degraded into peptide-bound amino acids (PBAAs), free amino acids (FAAs), and ultimately into ammonia by the rumen microbes. Both PBAA and FAA are milk protein precursors, and the rumen and small intestines are the main sites where such precursors are produced and absorbed. This work was designed to investigate the expression of the peptide transporter PepT1 and the AA transporters ASCT2, $y^{+} L A T 1$, and $A T B^{0,+}$, and the concentrations of PBAA, FAA, and soluble protein in the rumen, omasum, and duodenum of dairy cows. Tissues and digesta were collected from six healthy Chinese Holstein dairy cows immediately after the animals were slaughtered. The expression of transporters was analyzed by real-time quantitative polymerase chain reaction (PCR). The FAA concentration was assessed using an amino acid (AA) analyzer, PBAA concentration by quantification of $\mathrm{AA}$ before and after acid-hydrolysis by $6 \mathrm{~mol} / \mathrm{L} \mathrm{HCl}$, and soluble protein concentration by quantification of the bicinchoninic acid content. The results showed that the relative abundance of mRNA of the transporters and the soluble non-ammonia nitrogen (SNAN) concentration of each fraction were greater in the duodenum than in the rumen or omasum. These results indicate that the duodenum is the predominant location within the nonmesenteric digestive tract for producing milk protein precursors. In addition, PBAA was the largest component of SNAN in the digesta from the rumen, omasum, and duodenum. In conclusion, the duodenum has the greatest concentrations of SNAN and PBAA, and the greatest potential for absorption of SNAN in the form of PBAA in the nonmesenteric gastrointestinal tissues of dairy cows.
\end{abstract}

Key words: Soluble non-ammonia nitrogen, Nonmesenteric gastrointestine, Transporters, Dairy cows doi:10.1631/jzus.B1400299

\section{Introduction}

Protein, as one of the most important nutrients for ruminants, is gradually degraded by microbes into peptide-bound amino acids (PBAAs), free amino acids (FAAs), and ultimately ammonia after entering the rumen. Then, the PBAA, FAA, and ammonia are used for the synthesis of microbial protein by rumen

\footnotetext{
${ }^{\ddagger}$ Corresponding author

${ }^{\S}$ The two authors contributed equally to this work

* Project supported by the National Basic Research Program (973) of China (No. 2011CB100801)

(DD ORCID: Qing-biao XU, http://orcid.org/0000-0001-8461-9924

(c) Zhejiang University and Springer-Verlag Berlin Heidelberg 2015
}

microbes. Some dietary soluble protein can escape ruminal degradation and increase the supply of amino acid (AA) for milk production (Choi et al., 2002c). Soluble non-ammonia nitrogen (SNAN) in omasal digesta (OD) indicates the presence of the terminal products of rumen degradation and partly constitutes the liquid phase nitrogen available for entering the intestine (Oh et al., 2008). Previous reports have found that a significant amount of nitrogen $(\mathrm{N})$ can escape degradation in the rumen in the form of peptides and supply AAs for the intestine, especially in the proximal part (Volden et al., 2002; Rémond et al., 2009). PBAA and FAA constitute milk protein precursors (Tagari et al., 2008), and the rumen and small 
intestine may be the main parts of the gastrointestine where such precursors are produced and absorbed (Zhao et al., 2012). Peptides are hydrolyzed inside enterocytes and AAs are released together with those absorbed by AA transporters. Through the blood circulation, AAs are delivered mainly to the mammary gland where they serve as building blocks for milk protein synthesis. The main site of peptide adsorption is nonmesenteric-drained viscera, and nonmesenteric drainage coming from the rumen, reticulum, omasum, abomasum, duodenum and spleen (Webb et al., 1993). The duodenum is an important component of the digestive tract, forming part of the nonmesenteric system and small intestine. Many studies concerning the rumen and omasum have been published, but few have investigated the concentration and proportion of peptides and other forms of SNAN in the rumen, omasum, and duodenum.

Peptides have their own transport systems independent of those responsible for transporting FAA (Webb, 1990). It is generally recognized that the main method of absorption is by intermediate peptide transporters. AAs are transported by different transporter systems. However, in the small intestine, omasum, and rumen of sheep and dairy cows peptides are transported mainly by peptide transporter 1 (PepT1) (Gilbert et al., 2008). Transporter ASCT2 is a neutral AA transporter and $y^{+} L A T 1$ is a cationic transporter, and both are expressed in the apical membrane of the small intestine. $A T B^{0,+}$ can transport both neutral and cationic AAs and is expressed in the basolateral membrane of the small intestine (Bröer, 2008; Liao et al., 2008; 2009). However, the expression profiles of these transporters in the nonmesenteric gastrointestinal tissues of dairy cows are unknown. Therefore, the purpose of this study was to investigate the SNAN concentrations of each fraction in the rumen, omasum, and duodenum, the proportion of peptides, and the expression of PepTl and AA transporters on the membrane of the nonmesenteric gastrointestine.

\section{Materials and methods}

\subsection{Animal management}

Six healthy Chinese Holstein dairy cows in late

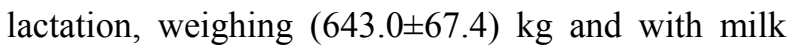

production of $(13.40 \pm 2.05) \mathrm{kg} / \mathrm{d}$, were killed by stunning with a captive-bolt pistol, followed by exsanguination. Before slaughter, the cows were separately housed in individual tie-stalls with free access to water. To satisfy basic needs and standardize the rumen condition, a basal diet was fed to the cows twice daily, at 07:00 and 19:00. The proportions of dietary ingredients and the chemical composition of experimental feeds are shown in Table 1. Three hours elapsed between the last feed and the slaughtering of the cows.

Table 1 Proportion and chemical composition of dietary ingredients in the experimental diet and the intake of the animals

\begin{tabular}{lc}
\hline \multicolumn{1}{c}{ Item } & Proportion (\%) ${ }^{*}$ \\
\hline Dietary ingredient & \\
Silage corn & 23 \\
Chinese wildrye & 26 \\
DDGS $^{1}$ & 10 \\
Corn & 26 \\
Bran & 6.8 \\
Bean cake & 2 \\
Cottonseed meal & 4 \\
Additive-mineral and vitamin & 0.3 \\
CaHPO & 1.4 \\
Salt & 0.5 \\
Composition & \\
Dry matter & 76.9 \\
Crude protein & 11.0 \\
Ether extract & 3.3 \\
Ash & 4.2 \\
Neutral detergent fiber & 31.0 \\
Acid detergent fiber & 19.8 \\
Intake & $15.2(\mathrm{~kg} / \mathrm{d})$ \\
\hline${ }^{1}$ Distillers dried grains with solubles. ${ }^{*}$ All data are expressed as \\
percentage except for intake $(\mathrm{kg} / \mathrm{d})$
\end{tabular}

\subsection{Real-time quantitative polymerase chain re- action (qPCR) of transporter mRNA}

Ruminal, omasal, and duodenal epithelium were taken from the cows immediately after slaughter. Total RNA was extracted using a TRIzol kit (Invitrogen, USA). The purity and quantity of total RNA were measured using a NANODROP 2000 Spectrophotometer (Thermo, USA). RNA of all samples had a ratio of optical density at $260 \mathrm{~nm}$ to that at $280 \mathrm{~nm}$ between 1.8 and 2.0. Synthesis of cDNA was carried out using PrimeScript RT reagent Kit Perfect Real Time (TaKaRa, Shiga, Japan). The primers for PepT1 and GAPDH were from Xu et al. (2014). The primers of $A S C T 2, y^{+} L A T 1$, and $A T B^{0,+}$, separated by at least 
one intron on the corresponding genomic DNA, were designed and synthesized (Biotechnology, China) as in Table 2. The qPCR of reverse-transcription products was performed using an ABI Prism 7500 Sequence Detection System (Applied Biosystems, USA). Components of a $20-\mu \mathrm{l}$ qPCR reaction were used according to the manufacturer's protocol (TaKaRa). The PCR conditions were $95{ }^{\circ} \mathrm{C}$ for $30 \mathrm{~s}$, 40 cycles of $95^{\circ} \mathrm{C}$ for $5 \mathrm{~s}$ and $60^{\circ} \mathrm{C}$ for $34 \mathrm{~s}$ using a continuous fluorescence measurement. Sequencing of the amplified PCR products showed a $100 \%$ match to known bovine DNA sequences in GenBank. Each cDNA sample from each cow was analyzed in triplicate. $G A P D H$ was chosen as a housekeeping gene. The same quantity of cDNA from each tissue was used for qPCR to maintain the $C_{\mathrm{T}}$ value of $G A P D H$ among different tissues.

\subsection{Sampling and chemical analysis}

Ruminal digesta (RD), omasal digesta (OD) and duodenal digesta (DD) were taken from the cows immediately after slaughter. The digesta were collected in 50-ml centrifuge tubes and immediately frozen $\left(-80{ }^{\circ} \mathrm{C}\right)$. Before the analysis, RD and DD were kept in an ice bath and then filtered through 8 layers of gauze. A total of $50 \mathrm{ml}$ of filtrate was saved for later experiments. Five grams of ODs were mixed with $30 \mathrm{ml}$ of McDougall's buffer in a ratio of 1:6 (w/v) (McDougall, 1948), and kept in an ice bath for $24 \mathrm{~h}$. The digesta was made according to the procedure proposed by Choi et al. (2002b). All the filtrates were centrifuged at $20000 \times \mathrm{g}$ for $15 \mathrm{~min}$ at $4{ }^{\circ} \mathrm{C}$ to eliminate small particles and rumen protozoa and bacteria. Once completed, the supernatant was divided into two portions: one was assigned to the assessment of SNAN concentration (FAA-N), and the other was hydrolyzed by trichloroacetic acid. The trichloroacetic acid was substituted by $25 \%$ perchloric acid, and the supernatant was divided into three parts to measure the concentrations of FAA, peptides, and soluble protein. Concentrations of soluble FAA in the supernatant without hydrolysis were determined using an AA analyzer (Biochrom 20, Pharmacia Biotech Ltd., Cambridge, UK). The peptide concentration was estimated as $\mathrm{N}$ from hydrolysed supernatant minus $\mathrm{N}$ present as FAA. Soluble protein was estimated from the hydrolysis of bicinchoninic acid and quantified by its optical density at $562 \mathrm{~nm}$ using a microplate reader (Molecular Devices, USA), based on the standard curve of bovine serum albumin. The tissues of the rumen, omasum, and duodenum were immediately taken from the cows after slaughter. The duodenal mucosa was scraped from the proximal part of the small intestine. The rumen and omasal papillae were sheared from rumen and omasal tissues. The epithelium was scraped from tissues and frozen in 1.5-ml centrifuge tubes at $-80{ }^{\circ} \mathrm{C}$.

\subsection{Calculations and statistical analysis}

To quantify the expression of PepT1 and AA transporters, the relative quantification method proposed by Schmittgen and Livak (2008) was used. In this study, the SNAN concentration of each fraction was calculated for the $50 \mathrm{ml}$ of fluid or digesta of the gastrointestine, as described by Choi et al. (2002b; $2002 \mathrm{c}): \quad C_{\mathrm{FAA}-\mathrm{N}}=C_{\mathrm{FAA}} / 6.25 ; \quad C_{\mathrm{PBAA}-\mathrm{N}}=\left(C_{\mathrm{TAA}}-C_{\mathrm{FAA}}\right) /$ 6.25 ; $C_{\text {soluble protein }{ }_{\mathrm{N}}}=C_{\mathrm{psp}} / 6.25$, where $C_{\mathrm{FAA}}$ is the concentration of FAA in the supernatant, $C_{\mathrm{TAA}}$ is the concentration of FAA after hydrolyzing by $6 \mathrm{~mol} / \mathrm{L}$ $\mathrm{HCl}$, and $C_{\mathrm{psp}}$ is the concentration of protein quantified by bicinchoninic acid.

The rumen was used as calibrator and $G A P D H$ was used as an internal control: $-\Delta \Delta C_{\mathrm{T}}=\left(C_{\mathrm{T}}\right.$, gene of interest, $\mathrm{A}-C_{\mathrm{T}}$, internal control, $\left.\mathrm{A}\right)-\left(C_{\mathrm{T}}\right.$, gene of interest, $\mathrm{B}-C_{\mathrm{T}}$, internal control, B), where sample B was the calibrator and sample A was a sample from one of the other two parts

Table 2 Primers used for real-time quantitative PCR

\begin{tabular}{cllc}
\hline Gene & \multicolumn{1}{c}{ GenBank ID } & \multicolumn{1}{c}{ Sense/antisense primer $\left(5^{\prime} \rightarrow 3^{\prime}\right)$} & Product size $(\mathrm{bp})$ \\
\hline PepT1 & NM_001099378 & TGGCTGGGGAAGTTCAAGAC/ & 239 \\
& & TCCTGGCCCTCTTCAAA & 119 \\
ASCT2 & NM_174601.2 & CTTGATCTTGGCCGTGGACT/ & 138 \\
& & AGTTGCAGTTCTCTGTGCGA & 150 \\
$y^{+}$LAT1 & NM_001075151.1 & AGGCTGGTCTCTGTGTGGTT/ & 150 \\
& & CTGGGAGGCCACTTCATACT & 197 \\
ATB ${ }^{0,+}$ & NM_001098461.1 & GCTGGTGTATGATTACTTTCTGC/ & CCCCACGATGTTTTCCAAG \\
& AJ000039 & GCCAAGAGGGTCATCATCTC/ & GGTCATAAGTCCCTCCACGA \\
\hline
\end{tabular}


of the digestive tract. The sample with the lowest $\Delta C_{\mathrm{T}}$ was used as calibrator within each comparison. For the calculation of PepTl expression, the rumen was chosen as calibrator, and for AA transporters, the omasum was chosen. The relative change in the PepT1 mRNA was calculated using the $2^{-\Delta \Delta C_{\mathrm{T}}}$ method (Livak and Schmittgen, 2001).

The experimental data were statistically analyzed by analysis of variance (ANOVA) and Duncan's multiple range tests using SAS method Version 9 (SAS Institute Inc., Cary, NC, USA). The data are presented as the mean \pm standard error (SE). A level of $P<0.05$ was accepted as being statistically significant.

\section{Results}

\section{1 mRNA expression of PepTI and AA transport- ers in the rumen, omasum, and duodenum}

Expression of PepT1, ATB $B^{0,+}, A S C T 2$, and $y^{+}$LAT1 in the duodenum was significantly higher than that in the rumen and omasum (Fig. 1) $(P<0.05)$. PepT1 expression in the duodenum was 20.1-fold greater than that in the rumen and 14.3-fold greater than that in the omasum. $A T B^{0,+}$ expression in the duodenum was 33.7-fold greater than that in the rumen and 310.6-fold greater than that in the omasum. The expression of ASCT2 in the duodenum was 1.65-fold greater than that in the rumen and 3.1-fold greater than that in the omasum. $y^{+} L A T 1$ expression in the duodenum was 11.0-fold greater than that in the rumen and 55.7-fold greater than that in the omasum.

\subsection{Concentrations of FAA- $N$ and PBAA- $N$ in ruminal, omasal, and duodenal digesta}

The forage-to-concentrate ratio was 50:50. Mean concentrations of FAA-N ( $\mathrm{N}$ in the form of FAA), PBAA-N, and soluble protein $\mathrm{N}$ are shown in Table 3 . The SNAN concentrations of each fraction of the duodenum were 3.8 to 5 times higher than those of the omasum $(P<0.01)$, and 7 to 11 times higher than those of the rumen. The ruminal SNAN concentrations of each fraction were 1.8 to 2.2 times lower than those in the omasum. PBAA constituted the largest proportion of SNAN, namely $44.4 \%$ to $51.6 \%$, from the duodenum to the rumen. All FAA-N concentrations except Pro in the duodenum were significantly higher than those in the rumen and omasum (Table 4$)(P<0.01)$. Most (a)

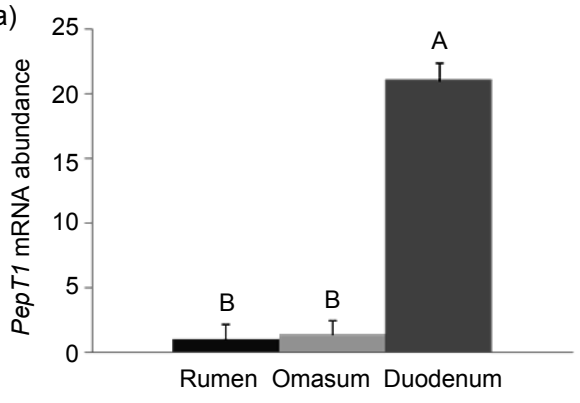

(c)

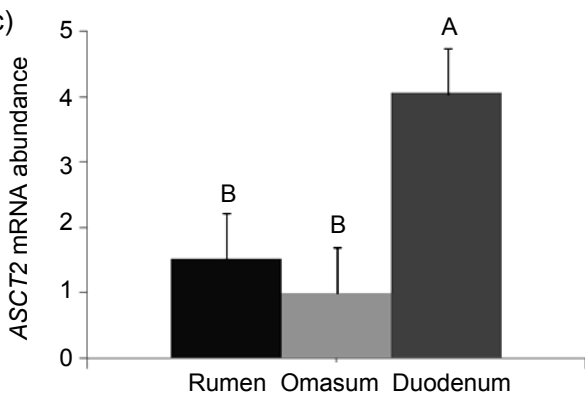

(b)

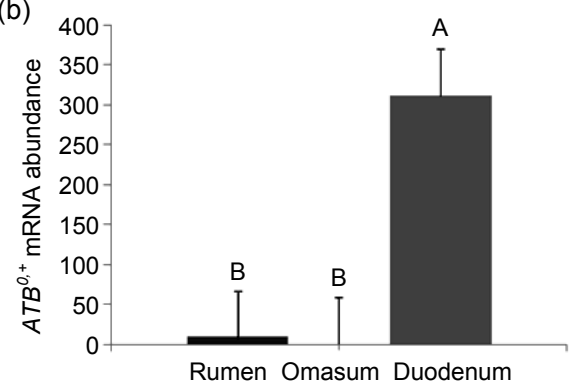

(d)

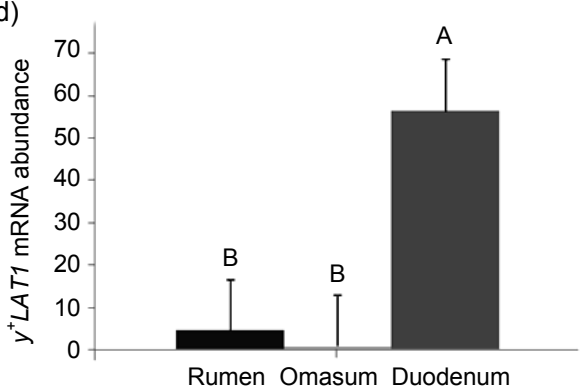

Fig. 1 Relative expression of PepT1 and AA transporters in the rumen, omasum and duodenum The mRNA expression of PepT1, $A T B^{0,+}, A S C T 2$, and $y^{+} L A T 1$ in the duodenum was higher than that in the rumen and omasum ( $2^{-\Delta \Delta C_{\mathrm{T}}}$ value). For the calculation of PepT1 expression, the rumen was chosen as calibrator (a), and for AA transporters, the omasum was chosen as calibrator (b, c, d). Values with different letters (A and B) are considered to be significantly different $(P<0.05)$. Data are expressed as mean $\pm \operatorname{SE}(n=6)$ 
PBAA-N concentrations in the duodenum were significantly higher than those in the rumen and omasum $(P<0.01)$. In addition, cysteine and cystine were oxidatively degraded, due to the use of $\mathrm{HCl}$ in the pretreatment.

Table 3 SNAN concentrations of each fraction in the ruminal, omasal, and duodenal digesta $(n=6)$

\begin{tabular}{lccccc}
\hline \multirow{2}{*}{ Composition } & \multicolumn{2}{c}{ Concentration $(\mathrm{mg} \mathrm{N} / 100 \mathrm{ml})$} & \multirow{2}{*}{ SE } & \multirow{2}{*}{$P$-value } \\
\cline { 2 - 5 } & Ruminal & Omasal & Duodenal & & \\
\hline FAA-N & $22.42^{\mathrm{B}}$ & $49.87^{\mathrm{B}}$ & $189.77^{\mathrm{A}}$ & 24.504 & $<0.01$ \\
PBAA-N & $40.01^{\mathrm{B}}$ & $73.30^{\mathrm{B}}$ & $285.46^{\mathrm{A}}$ & 35.798 & $<0.01$ \\
$\begin{array}{c}\text { Soluble } \\
\quad \text { protein N }\end{array}$ & $15.10^{\mathrm{B}}$ & $34.57^{\mathrm{B}}$ & $168.41^{\mathrm{A}}$ & 16.394 & $<0.01$ \\
Total N & $77.53^{\mathrm{B}}$ & $157.73^{\mathrm{B}}$ & $643.64^{\mathrm{A}}$ & 65.757 & $<0.01$ \\
\hline $\begin{array}{l}\text { PBAA-N/ } \\
\quad \text { Total N }\end{array}$ & $51.6 \%$ & $46.5 \%$ & $44.4 \%$ & & \\
\hline
\end{tabular}

SE: standard error of means. Values in the same row with different letters (A and B) are considered to be significantly different $(P<0.01)$

\section{Discussion}

Macromolecular proteins, DNA, and RNA can be precipitated by $25 \%$ perchloric acid. Peptides (of less than fifty AAs) can be hydrolyzed to FAAs by $\mathrm{HCl}$. Peptides greater than six AAs are generally thought to be cleaved to fewer than six AAs by pancreaticreleased proteases/peptidases. The smaller size peptides are then degraded into di- or tri-peptides and FAAs by a variety of peptidases in the apical membranes of intestinal epithelial cells (Clark et al., 1992). PBAAs entering the duodenum from the abomasum have two sources: microbial metabolism and digestion of microbial protein by gastric acid and pepsin. In this study, more of the duodenal PBAA may have come from microbial protein due to the low lactation yield of the dairy cows, the requirements of which can be almost met by the microbial protein alone (Zhu et al., 2013). In addition, digesta represent serial events resulting in concentrations that are not proportional to absorption events. For example, omasal digesta is concentrated relative to rumen and duodenal digesta and, at least in vitro, omasal tissue appears to have a greater capacity for dipeptide absorption than does ruminal tissue (Matthews and Webb, 1995; Matthews et al., 1996; McCollum et al., 2000). Therefore, we investigated the expression of peptide and AA transporters and the concentrations of PBAA, FAA and soluble protein in the rumen, omasum, and duodenum of dairy cows to find out which organ has the greatest potential to absorb SNAN in nonmesenteric gastrointestinal tissues.

Table 4 Concentrations of 16 types of amino acids in the forms of FAA-N and PBAA-N in the ruminal, omasal, and duodenal digesta $(n=6)$

\begin{tabular}{|c|c|c|c|c|c|c|c|c|c|c|}
\hline \multirow{3}{*}{ AA } & \multicolumn{5}{|c|}{ FAA-N } & \multicolumn{5}{|c|}{ PBAA-N } \\
\hline & \multicolumn{3}{|c|}{ Concentration (mg N/100 ml) } & \multirow{2}{*}{ SE } & \multirow{2}{*}{$P$-value } & \multicolumn{3}{|c|}{ Concentration (mg N/100 ml) } & \multirow{2}{*}{ SE } & \multirow{2}{*}{$P$-value } \\
\hline & Ruminal & Omasal & Duodenal & & & Ruminal & Omasal & Duodenal & & \\
\hline Asp & $1.82^{\mathrm{B}}$ & $3.13^{\mathrm{B}}$ & $9.70^{\mathrm{A}}$ & 1.522 & 0.0050 & $5.623^{\mathrm{B}}$ & $13.759^{\mathrm{B}}$ & $37.195^{\mathrm{A}}$ & 4.855 & 0.0010 \\
\hline Thr & $1.38^{\mathrm{B}}$ & $2.14^{\mathrm{B}}$ & $12.53^{\mathrm{A}}$ & 2.074 & 0.0027 & $1.578^{\mathrm{B}}$ & $4.996^{\mathrm{BA}}$ & $9.456^{\mathrm{A}}$ & 1.603 & 0.0117 \\
\hline Ser & $1.24^{\mathrm{B}}$ & $2.79^{\mathrm{B}}$ & $14.75^{\mathrm{A}}$ & 2.128 & 0.0008 & $1.888^{\mathrm{B}}$ & $7.588^{\mathrm{BA}}$ & $11.277^{\mathrm{A}}$ & 1.511 & 0.0019 \\
\hline Glu & $3.90^{\mathrm{B}}$ & $12.03^{\mathrm{BA}}$ & $22.37^{\mathrm{A}}$ & 3.037 & 0.0024 & $6.129^{\mathrm{B}}$ & $9.762^{\mathrm{B}}$ & $49.652^{\mathrm{A}}$ & 7.137 & 0.0010 \\
\hline Pro & $0.04^{\mathrm{A}}$ & $0.13^{\mathrm{A}}$ & $0.06^{\mathrm{A}}$ & 0.088 & 0.7320 & $2.973^{\mathrm{B}}$ & $-0.133^{\mathrm{B}}$ & $21.687^{\mathrm{A}}$ & 2.885 & 0.0002 \\
\hline Gly & $0.88^{\mathrm{B}}$ & $1.72^{\mathrm{B}}$ & $10.58^{\mathrm{A}}$ & 1.280 & 0.0001 & $3.325^{\mathrm{B}}$ & $6.439^{\mathrm{B}}$ & $28.103^{A}$ & 2.451 & $<0.0001$ \\
\hline Ala & $1.29^{\mathrm{B}}$ & $3.83^{\mathrm{B}}$ & $11.52^{\mathrm{A}}$ & 1.620 & 0.0012 & $3.228^{\mathrm{B}}$ & $4.799^{\mathrm{B}}$ & $14.891^{\mathrm{A}}$ & 1.961 & 0.0015 \\
\hline Val & $1.12^{\mathrm{B}}$ & $2.42^{\mathrm{B}}$ & $10.77^{\mathrm{A}}$ & 1.656 & 0.0017 & $1.383^{\mathrm{B}}$ & $2.049^{\mathrm{B}}$ & $12.952^{\mathrm{A}}$ & 1.944 & 0.0011 \\
\hline Met & $0.44^{\mathrm{B}}$ & $1.47^{\mathrm{B}}$ & $7.90^{\mathrm{A}}$ & 0.976 & 0.0001 & $-0.334^{\mathrm{BA}}$ & $-0.766^{\mathrm{B}}$ & $3.050^{\mathrm{A}}$ & 0.831 & 0.0102 \\
\hline Ile & $1.09^{\mathrm{B}}$ & $1.92^{\mathrm{B}}$ & $8.39^{\mathrm{A}}$ & 1.396 & 0.0039 & $1.242^{\mathrm{B}}$ & $2.080^{\mathrm{B}}$ & $11.934^{\mathrm{A}}$ & 1.135 & $<0.0001$ \\
\hline Leu & $1.59^{\mathrm{B}}$ & $2.77^{\mathrm{B}}$ & $17.79^{\mathrm{A}}$ & 2.468 & 0.0005 & $1.614^{\mathrm{B}}$ & $2.304^{\mathrm{B}}$ & $19.309^{\mathrm{A}}$ & 3.371 & 0.0029 \\
\hline Tyr & $1.05^{\mathrm{B}}$ & $1.82^{\mathrm{B}}$ & $9.81^{\mathrm{A}}$ & 1.511 & 0.0015 & $0.969^{\mathrm{B}}$ & $2.661^{\mathrm{BA}}$ & $7.902^{\mathrm{A}}$ & 1.342 & 0.0063 \\
\hline Phe & $0.97^{\mathrm{B}}$ & $1.83^{\mathrm{B}}$ & $11.63^{\mathrm{A}}$ & 1.860 & 0.0017 & $1.109^{\mathrm{A}}$ & $1.683^{\mathrm{A}}$ & $6.460^{\mathrm{A}}$ & 1.474 & 0.0412 \\
\hline His & $1.55^{\mathrm{B}}$ & $6.02^{\mathrm{BA}}$ & $10.32^{\mathrm{A}}$ & 1.271 & 0.0008 & $4.568^{\mathrm{A}}$ & $9.045^{\mathrm{A}}$ & $8.584^{\mathrm{A}}$ & 1.615 & 0.132 \\
\hline Lys & $3.12^{\mathrm{B}}$ & $7.08^{\mathrm{BA}}$ & $14.39^{\mathrm{A}}$ & 1.754 & 0.0013 & $3.179^{\mathrm{B}}$ & $1.809^{\mathrm{B}}$ & $29.425^{\mathrm{A}}$ & 4.015 & 0.0003 \\
\hline Arg & $0.93^{\mathrm{B}}$ & $1.14^{\mathrm{B}}$ & $17.27^{\mathrm{A}}$ & 2.594 & 0.0050 & $1.540^{\mathrm{B}}$ & $5.226^{\mathrm{BA}}$ & $13.586^{\mathrm{A}}$ & 2.061 & 0.0027 \\
\hline EAA & $13.25^{\mathrm{B}}$ & $28.63^{\mathrm{B}}$ & $120.79^{\mathrm{A}}$ & 16.619 & 0.0007 & $16.85^{\mathrm{B}}$ & $31.09^{\mathrm{B}}$ & $122.66^{\mathrm{A}}$ & 16.867 & 0.0009 \\
\hline NEAA & $9.17^{\mathrm{B}}$ & $23.64^{\mathrm{B}}$ & $68.98^{\mathrm{A}}$ & 8.841 & 0.0006 & $23.17^{\mathrm{B}}$ & $42.21^{\mathrm{B}}$ & $162.80^{\mathrm{A}}$ & 19.655 & 0.0003 \\
\hline
\end{tabular}

SE: standard error of means; EAA: essential amino acids; NEAA: non-essential amino acids. Values in the same row with different letters (A and B) are considered to be significantly different $(P<0.01)$ 
The expression of AA transporters in the duodenum was significantly higher than that in the rumen and omasum (Fig. 1). ASCT2 is a high-affinity neutral AA transporter at the apical membrane and can interact with anionic AAs at the low $\mathrm{pH}$ of the intestine, especially glutamate (Bröer, 2008). $A T B^{0,+}$ is a highaffinity neutral and cationic AA transporter expressed at the apical membrane. Liao et al. (2009) found $A T B^{0,+}$ and $y^{+} L A T 1$ mRNA expression in the duodenum, jejunum, and ileum of cattle (growing steers), and mRNA expression by duodenal epithelia was greater than that by the jejunum or ileum. The trend of expression of $y^{+} L A T 1$ and $A T B^{0,+}$ mRNA was relevant to our current findings. Briefly, their expression was highest in the duodenum. This result indicates that the duodenum may have a greater capability for the absorption of neutral and cationic AAs than the rumen and omasum. In addition, the concentration of FAA-N in the duodenum was greater than those in the rumen and omasum (Tables 3 and 4). This result agrees with previous studies reporting that AAs escape from the rumen due to the degradation of protein by rumen microbes and enter the duodenum, thus differing from those in the feed consumed (Piepenbrink and Schingoethe, 1998; Taghizadeh et al., 2005). Incubation of the intestine also has a considerable effect on AA profiles for all feedstuffs. For most feedstuffs, this can be explained by the fact that secretions of trypsin, chymotrypsin, elastase, and carboxypeptidases A and B from the pancreas show specificity for PBAA. Their maximal activity occurs in the proximal segments of the small intestine (Chen et al., 1987; Taghizadeh et al., 2005). In the present study, concentrations of PB-Thr, PB-Tyr, PB-Phe, and PB-Arg in the omasum were different from those in the duodenum, confirming the activity of pancreatic enzymes. Although both AA concentrations and AA transporter mRNA expression were greater, the magnitude of the AA concentration was much less than that of mRNA expression. The concentration of AAs and the expression of AA transporters in the duodenum were significantly higher than those in the rumen and omasum.

In this study, the mean concentrations of FAA-N were lower than published values $(6.30-33.37 \mathrm{mg} \mathrm{N} / \mathrm{L}$ and $12.20-56.23 \mathrm{mg} \mathrm{N} / \mathrm{L}$, respectively) (Choi et al., 2002a; 2002b; 2002c; Choi and Choi, 2003). One reason may be that incomplete acid precipitation of proteins results in overestimated peptide fractions, as discussed by Reynal et al. (2007). The dietary protein proportion $(11 \%)$ was lower than that found in previous studies (Choi et al., 2002a; 2002b; 2002c; Choi and Choi, 2003). The relatively low dietary protein led to less degradation of protein into SNAN and less use of available SNAN by rumen microbes. Thus, less microbial protein was provided to the duodenum. Another reason may be that different methods to deal with the digesta resulted in different SNAN concentrations left in the liquid phase of the digesta. In addition, small peptides can be absorbed by PepTI by the epithelial cells of the gastrointestinal tract without further degradation (Xu et al., 2014). The expression of PepTl increased significantly from the rumen to the duodenum, but not significantly between the rumen and the omasum (Fig. 1). This result indicates that the duodenum may be the major nonmesenteric gastrointestine for peptide absorption. In addition, the trend of PBAA-N concentrations was similar to the trend of PepT1 expression in the rumen, omasum, and duodenum. This may be because peptides stimulate the expression of PepT1 to transport more peptides across the epithelium. PepTl increased with the increase in peptide concentration in the nonmesenteric gastrointestine. In this study, the concentrations of PBAA-N increased from the rumen to the duodenum. This may be because some PBAA-N was used by rumen microbes, and microbial protein was degraded into PBAA by the large number of peptidase enzymes in the duodenum (Clark et al., 1992). These results confirm that the duodenum is the major nonmesenteric gastrointestine for peptide absorption. In addition, we found that PBAA-N concentrations accounted for about half of the SNAN. This result suggests that PBAA has an important role in SNAN absorption. The proportion of PBAA-N was lower than that found in some previous studies (Choi et al., 2002a; 2002b; 2002c; Choi and Choi, 2003). One reason may be that incomplete acid precipitation of proteins results in overestimated peptide fractions, as discussed by Reynal et al. (2007). Another reason may be that the methods to deal with the digesta may result in different SNAN concentrations left in the liquid phase of the digesta. In this study, a low crude protein diet was used to feed cows with low yield lactation. In China, there are many small and medium dairy farms using Chinese Holstein dairy cows with a 
low milk yield. If a higher crude protein diet was used to feed the cows, the distribution and the proportion of all kinds of SNAN may be similar to those in this study due to the similar gastrointestinal environment.

In conclusion, the mRNA expression of three AA transporters and PepTl in the duodenum was highest in the nonmesenteric gastrointestine, as were the concentrations of FAA-N and PBAA-N. This common trend indicates that the duodenum is the major nonmesenteric site for absorbing SNAN. Moreover, PBAA-N concentrations accounted for the largest part of SNAN, suggesting that PBAA has an important role in SNAN absorption and confirming results from previous studies. These results can be used to improve feed regulation and gastrointestinal metabolism to increase milk protein yield and $\mathrm{N}$ efficiency.

\section{Compliance with ethics guidelines}

Ying-ming XIE, Qing-biao XU, Yue-ming WU, Xin-bei HUANG, and Jian-xin LIU declare that they have no conflict of interest.

All institutional and national guidelines for the care and use of laboratory animals were followed.

\section{References}

Bröer, S., 2008. Amino acid transport across mammalian intestinal and renal epithelia. Physiol. Rev., 88(1):249286. [doi:10.1152/physrev.00018.2006]

Chen, G., Russell, J.B., Sniffen, C.J., 1987. A procedure for measuring peptides in rumen fluid and evidence that peptide uptake can be a rate-limiting step in ruminal protein degradation. J. Dairy Sci., 70(6):1211-1219. [doi:10.3168/jds.S0022-0302(87)80133-9]

Choi, C.W., Choi, C.B., 2003. Flow of soluble non-ammonia nitrogen in the liquid phase of digesta entering the omasum of dairy cows given grass silage based diets. Asian Australas. J. Anim. Sci., 16(10):1460-1468. [doi:10.5713/ ajas.2003.1460]

Choi, C.W., Vanhatalo, A., Huhtanen, P., 2002a. Concentration and estimated flow of soluble non-ammonia nitrogen entering the omasum of dairy cows as influenced by different protein supplements. Agric. Food Sci. Finland, 11(2):79-91.

Choi, C.W., Ahvenjärvi, S., Vanhatalo, A., et al., 2002b. Quantitation of the flow of soluble non-ammonia nitrogen entering the omasal canal of dairy cows fed grass silage based diets. Anim. Feed Sci. Tech., 96(3-4):203-220. [doi:10.1016/S0377-8401(01)00348-0]

Choi, C.W., Vanhatalo, A., Ahvenjärvi, S., et al., 2002c. Effects of several protein supplements on flow of soluble non-ammonia nitrogen from the forestomach and milk production in dairy cows. Anim. Feed Sci. Tech.,
102(1-4):15-33. [doi:10.1016/S0377-8401(02)00251-1]

Clark, J.H., Klusmeyer, T.H., Cameron, M.R., 1992. Symposium: nitrogen metabolism and amino acid nutrition in dairy cattle microbial protein synthesis and flows of nitrogen fractions to the duodenum of dairy cows. J. Dairy Sci., 75(8):2304-2323. [doi:10.3168/jds.S0022-0302(92) 77992-2]

Gilbert, E.R., Wong, E.A., Webb, K.E.Jr., 2008. Board-invited review: peptide absorption and utilization: implications for animal nutrition and health. J. Anim. Sci., 86(9):21352155. [doi:10.2527/jas.2007-0826]

Liao, S.F., Vanzant, E.S., Boling, J.A., et al., 2008. Identification and expression pattern of cationic amino acid transporter-1 mRNA in small intestinal epithelia of Angus steers at four production stages. J. Anim. Sci., 86(3):620631. [doi:10.2527/jas.2006-727]

Liao, S.F., Vanzant, E.S., Harmon, D.L., et al., 2009. Ruminal and abomasal starch hydrolysate infusions selectively decrease the expression of cationic amino acid transporter mRNA by small intestinal epithelial of forage-fed beef steers. J. Dairy Sci., 92(3):1124-1135. [doi:10.3168/jds. 2008-1521]

Livak, K.J., Schmittgen, T.D., 2001. Analysis of relative gene expression data using real-time quantitative PCR and the $2^{-\Delta \Delta C_{\mathrm{T}}}$ method. Methods, 25(4):402-408. [doi:10.1006/ meth.2001.1262]

Matthews, J.C., Webb, K.E.Jr., 1995. Absorption of L-carnosine, L-methionine, and L-methionylglycine by isolated sheep ruminal and omasal epithelial tissue. $J$. Anim. Sci., 73(11):3464-3475.

Matthews, J.C., Wong, E.A., Bender, P.K., et al., 1996. Demonstration and characterization of dipeptide transport system activity in sheep omasal epithelium by expression of mRNA in Xenopus laevis oocytes. J. Anim. Sci., 74(7): 1720-1727.

McCollum, M.Q., Vazquez-Anon, M., Dibner, J.J., et al., 2000. Absorption of 2-hydroxy-4-(methylthio) butanoic acid by isolated sheep ruminal and omasal epithelia. J. Anim. Sci., 78(4): 1078-1083.

McDougall, E.I., 1948. Studies on ruminant saliva: the composition and output of sheep saliva. J. Biochem., 43(1): 99-109.

Oh, Y.K., Kim, J.H., Kim, K.H., et al., 2008. Effects of level and degradability of dietary protein on ruminal fermentation and concentrations of soluble non-ammonia nitrogen in ruminal and omasal digesta of Hanwoo steers. Asian Australas. J. Anim. Sci., 21(3):392-403. [doi:10. 5713/ajas.2008.70342]

Piepenbrink, M.S., Schingoethe, D.J., 1998. Ruminal degradation, amino acid composition, and estimated intestinal digestibilities of four protein supplements. J. Dairy Sci., 81(2):454-461. [doi:10.3168/jds.S0022-0302(98)75597-3]

Rémond, D., Bernard, L., Savary-Auzeloux, I., et al., 2009. Partitioning of nutrient net fluxes across the portaldrained viscera in sheep fed twice daily: effect of dietary protein degradability. Br. J. Nutr., 102(03):370-381. 
[doi:10.1017/S0007114508199470]

Reynal, S.M., Ipharraguerre, I.R., Liñeiro, M., et al., 2007. Omasal flow of soluble proteins, peptides, and free amino acids in dairy cows fed diets supplemented with proteins of varying ruminal degradabilities. J. Dairy Sci., 90(4): 1887-1903. [doi:10.3168/jds.2006-158]

Schmittgen, T.D., Livak, K.J., 2008. Analyzing real-time PCR data by the comparative $C_{\mathrm{T}}$ method. Nat. Protoc., 3(6): 1101-1108. [doi:10.1038/nprot.2008.73]

Tagari, H., Webb, K.E.Jr., Theurer, B., et al., 2008. Mammary uptake, portal-drained visceral flux, and hepatic metabolism of free and peptide-bound amino acids in cows fed steam-flaked or dry-rolled sorghum grain diets. J. Dairy Sci., 91(2):679-697. [doi:10.3168/jds.2007-0629]

Taghizadeh, A., Mesgaran, M.D., Valizadeh, R., et al., 2005. Digestion of feed amino acids in the rumen and intestine of steers measured using a mobile nylon bag technique. $J$. Dairy Sci., 88(5):1807-1814. [doi:10.3168/jds.S00220302(05)72855-1]

Volden, H., Mydland, L.T., Olaisen, V., 2002. Apparent ruminal degradation and rumen escape of soluble nitrogen fractions in grass and grass silage administered intraruminally to lactating dairy cows. J. Anim. Sci., 80(10): 2704-2716.

Webb, K.E.Jr., 1990. Intestinal absorption of protein hydrolysis products: a review. J. Anim. Sci., 68(9):3011-3022.

Webb, K.E.Jr., Dirienzo, D.B., Matthews, J.C., 1993. Recent development in gastrointestinal absorption and tissue utilization of peptides: a review. J. Dairy Sci., 76(1): 351-361. [doi:10.3168/jds.S0022-0302(93)77355-5]

Xu, Q.B., Wu, Y.M., Liu, H.Y., et al., 2014. Establishment and characterization of an omasal epithelial cell model derived from dairy calves for the study of small peptide absorption. PLoS ONE, 9(3):e88993. [doi:10.1371/journal. pone.0088993]

Zhao, J.W., Zhao, S.G., Sun, P., et al., 2012. The influence factors of synthesis and utilization in cow milk protein source precursor. Chin. Anim. Husb. Vet. Med., 39:78-81 (in Chinese).

Zhu, W., Tang, C.H., Sun, X.P., et al., 2013. Rumen microbial protein synthesis and milk performance in lactating dairy cows fed the fortified corn stover diet in comparison with alfalfa diet. J. Anim. Physiol. Anim. Nutr., 12(5):633-639. [doi:10.3923/javaa.2013.633.639]

\section{中文概要}

题 目: 十二指肠在奶牛非肠系膜系统中吸收可溶性非氨 态氮的潜在作用

目 的: 研究奶牛非肠系膜系统对可溶性非氨态氮的吸收 能力。

创新点: 目前国内外关于研究奶牛非肠系膜系统（瘤胃、 瓣胃和十二指肠) 内容物内可溶性非氨态氮和组 织内转运载体表达的关系非常少。本文研究了瘤 胃、瓣胃和十二指肠内可溶性非氨态氮的浓度, 并检测了这些组织内小肽和氨基酸转运载体 （PepT1、ASCT2、 $y^{+} L A T 1$ 和 $A T B^{0,+}$ ） 的表达量, 并进行了系统性的比较, 在底物和基因之间建立 了一定的联系。

方 法: 通过酸解法和氨基酸分析仪检测得到了瘤胃、瓣 胃和十二指肠内可溶性非氨态氮的浓度 (表 3 和 4), 并利用荧光定量聚合酶链反应（qRT-PCR） 检测了各组织部位的载体基因表达量（图 1）。

结 论: 十二指肠内容物的可溶性非氨态氮浓度最高, 并 且其载体的表达量也最大, 表明十二指肠在奶牛 非肠系膜系统中吸收可溶性非氨态氮的潜力最 大, 其中小肽在可溶性非氨态氮中占了大量比例。

关键词：可溶性非氨态氮; 非肠系膜系统; 转运载体; 奶牛 